\title{
Rakennemuutos ja aikuisväestön koulutus ${ }^{1)}$
}

Lehtisalo, Liekki 1988. Rakennusmuutos ja aikuisväestön koulutus. Aikuiskasvatus 8, 1. 13-18. - Artikkelissa tarkastellaan aikuiskoulutuksen mahdollisuuksia yhteiskunnan, työelämän ja kulttuurin rakennemuutosten hallinnan välineenä. Muutokset edellyttävät uudentyyppistä koko väestön koulutusstrategiaa, joka rakentuu joustavalle jatkuvan koulutuksen periaatteelle. Rakennemuutos merkitsee sïrtymistä teollisuusyhteiskunnan koulupolitiikasta jälkiteollisen yhteiskunnan koulutuspolitiikkaan. Uudella koulutuspolitiikalla on jokaiselle taattava elämisen laadun ja muutosten edellyttämä tieto-, taito-, osaamis- ja luovuusvaranto.

\section{Rakennemuutos \\ haastaa koulutuksen}

Meneillään olevan yhteiskunnan rakennemuutoksen yksiselitteinen määrittely ei ole ongelmatonta. Monet ovat sitä mieltä, että rakennemuutoksessa on perimmältään kysymys uuden tekniikan käyttöönoton laajaulotteisista vaikutuksista kaikkiin yhteiskunnan ja kulttuurin lohkoihin, koko ihmisen elämiseen ja elämäntapaan. Jo tänään täyttä todellisuutta oleva rakennemuutos voitaneen yksinkertaistaen määrittää prosessiksi, jossa teollisuusyhteiskunta asteittain muuttuu jälkiteolliseksi. Rakennemuutos on kansainvälistä ja se tapahtuu kiristyneen kansainvälisen kilpailun ja yhdentymisen leimaamassa taloudellisessa tilanteessa.

Yhteiskunnan kehityksen päävisio ja samalla koulutuksen tulevan toimintaympäristön kehys on siis jo näkyvissämme. Edellinen iso rakennemuutos vyörytti Suomen 60- ja 70-luvuilla uudenaikaiseksi teollisuus- ja osin myös palveluyhteiskunnaksi aloittaen samalla koulujärjestelmän asteittaisen uudistumisen. Nyt käynnissä oleva rakennemuutos näyttää varsin ripeästi siirtävän meitä jälkiteolliseen tieto- ja palveluyhteiskuntaan, minkä keskeis $\epsilon_{\text {ksi tunto- }}$ merkiksi kohoaa tieto erilaisissa jalostetuissa ja järjestelmällisissä muodoissa. Jolkut epäilijät pitävät tietoyhteiskuntaa huikeana harhana ja puhuvat mieluummin jäsentymàttömän informaation hallitsemattomasta tulvasta. Joka tapauksessa olemme kokemassa ir misen tie-

1) Perustuu Aikuiskoulutuksen arvot ja tavoitteet rakennemuutoksen keskellä — seminaarissa 17.3.1988 pidettyyn alustukseen. don ja tietämisen ennen näkemätöntä ekspansiota. Usein tuo tieto on painotetun teknistä: tietotekniikkaa, viestintätekniikkaa, biotekniikkaa. Yhä useammin tuote on kulutettava tieto, tiedosta tulee tavara.

Tiedon sisäistäminen perustavan laatuiseksi tuotannon tekijäksi, jonka rinnalla pääoma, työ ja maa ovat toissijaisia, on muuttamassa jopa kansainvälisiä toimintaympäristöjä ja -strategioita. Kun valtioiden välillä ruvetaan käymään kilpailua tiedon tason kohottamisesta, menestyksen keskeisiksi edellytyksiksi nousee niiden kyky luoda tehokkaita koulutusjärjestelmiä Koulutuksesta on tulossa kansainvälisen kilpailukyvyn keskeinen keino ja samalla uusi tason mittari.

Kansalaisten osaamisen, taitotiedon taso on nousemassa kansakunnan elämisen ja samalla sivistyksen tasoon olennaisimmin vaikuttavaksi tekijäksi. Tästä seuraa johdonmukaisesti voimakkaita koulutustarpeita ja välttämättömyys ruveta kehittämään uudentyyppistä koko kansan koulutusstrategiaa, joka rakentuu joustavalle jatkuvan koulutuksen periaatteelle ja jossa aikuisväestön koulutus nostetaan uudelle tasolle.

\section{Aikuisväestön koulutusajattelun painopistealueet}

Tärkeimmät aikuisväestön koulutuksen painotukset lähivuosina ja 90-luvulla keskittyvät oletettavasti 1) jatkuvan/elinikäisen koulutuksen todelliseen käytännön läpimurtoon, 2) siihen sisältyvään ammatillisen aikuiskoulutuksen korostumiseen sekä 3) koulutuksen käyttöön suomalaisen kulttc ikehityksen turvaajana ja edistäjänä. 
Merkittävimpiä viime aikojen keskustelupuheenvuoroja koulutuksesta on ollut pääministeri Harri Holkerin Joensuun konferenssissa pitämä, jossa hän totesi mm.: "1990-luvun yhteiskuntapolitiikan ykkösongelma-alue on koulutus; kansalaisten koko elinikäiseen oppimiseen siirtyminen ja järjestäminen. Nyt olisi viisaiden tehtävänä kiireellisesti laatia ehdotus koko väestön elinikäiseen koulutusjärjestelmään siirtymisestä.'

Puheen myönteistä painoarvoa ei vähäisimmässäkään määrin laimenna se, että opetusministeriössä on jatkuvan/elinikäisen koulutuksen periaatetta ja strategioita selvitetty viime vuosina varsin perusteellisesti. Samoin koulutuksen kehittämistä koskevissa osittaisratkaisuissa jatkuvan koulutuksen periaatetta on pyritty soveltamaan käytäntöön, joskaan ei riittävän järjestelmällisesti.

\section{Koulutuksen ja työn kohtalonyhteys}

Koulutuksen kohtalonkysymys tänään ja tulevaisuudessa on työ. Tähän asti suuressa määrin hallitsematon rakennemuutos näyttää kipeimmin ja hallitsemattomimmin iskevän yksilöä juuri perinpohjaisten teknologisten muutosten kouriin joutuneen työn ja ammatin alueella. Keskeisiä ongelmia on työvoiman kysynnän ja tarjonnan yhteensovittaminen. Mikäli tässä onnistuttaisiin, voitaisiin jo varsin hyvällä omallatunnolla puhua työelämän rakennemuutoksen hallinnasta. Koulutus puolestaan on työvoiman kysynnän ja tarjonnan yhteensovittamisessa yhä merkittävämpi keino, ehkä ratkaisevin.

Työn ja ammattien tulevaisuutta pohtiessaan monet yhteiskuntatieteilijät ovat viime vuosina päätyneet varsin synkin värein maalaamaan työyhteiskunnan kriisiä. Seuraavat väittämät eivät ole olleet harvinaisia: Työn määrä vähenee jopa ratkaisevasti, työ polarisoituu ja tekniikka köyhdyttää työn sisältc̈iä, vieraannuttaa ja passivoi työntekijää.

Miten työelämä sitten on muuttumassa ja tullee muuttumaan sekä mitä tästä kehityksestä seuraa yleensä koulutukseen ja erityisesti aikuisväestön koulutukseen 90-luvulla?

Elinkeinorakenteemme on viime vuosikymmeninä kokenut ratkaisevia muutoksia. Maa- ja metsätaloudesta toimeentulonsa saavien osuus oli 1950 noin 46 prosenttia, mutta 1985 enää 11 prosenttia. Samanaikaisesti palveluelinkeinoista toimeentulonsa saavien osuus kasvoi 25 prosentista 57 prosenttiin. Ensi vuosikymmenellä maa- ja metsätalouden osuus laskee alle 10 prosentin, teollisuuden alle 30 prosentin ja palveluelinkeinoista saa elantonsa jo kaksikolmasosaa työvoimasta. Elinkeinorakenteen muutokseen on kiinteästi liittynyt yhdyskuntarakenteen muutos, joka on merkinnyt vahvaa kaupungistumista ja urbanisoitumista.

Tarkasteltaessa työelämän toimialojen ja ammattirakenteiden tulevaisuutta voidaan suhteellisen varmasti ennakoida seuraavia pääsuuntia 1990-luvulle: Ruumiillisen työn ammattien, teollisuudessa ja alkutuotannossa, osuus ja absoluuttinen koko on pienentynyt jatkuvasti ja suunta on edelleen varsin nopeasti aleneva. Johtavan teknisen työn, ml. suunnittelun, kehittämisen ja tutkimuksen, arvioidaan kuten tähänkin asti kasvavan nopeasti, samoin taloudellis-hallinnollisen ja muun johtotyön määrä lisääntyy edelleen. Kulttuuri-, opetus-, kasvatus- ja vapaa-aikatyön määrä kasvaa niinikään nopeasti ja aivan erityisen voimakasta on terveys- ja sosiaalityön ammattien kasvu. Toimistotyöntekijöiden määrän tähänastinen kasvu taittuu; tietotekniikka vähentää ennen pitkää toimistotyöntekijöiden (ei sihteerien) tarvetta, mutta synnyttää toisaalta myös uusia tehtäviä. Kaupan alan työvoima saattaa vielä jonkin verran lisääntyä, mikä johtuu muun muassa osa-aikatyön kasvusta. Huolto- ja asennustyön määrä vähenee, samoin varastotyö automaation johdosta.

Jo edellä esitetty oikeuttaa nähdäkseni tekemään johtopäätöksen, että yleinen työn kriisistä ja rappiosta puhuminen on pahasti harhainen yleistys. Sen sijaan on kyllä vakavaa aihetta painottaa suorittavan fyysisen, yksinkertaisen ja vähän koulutusta edellyttävän palkkatyön joutuneen ilmeisesti lopulliseen kriisiin jo siksikin, että sen määrä jatkuvasti vähenee. Tässä olemme keskellä työelämän rakennemuutoksen yhtä ydintä: kysymys on deindustrialisaatiosta, vanhateollisten rakenteiden rapautumisesta ja purkautumisesta. Samalla se merkitsee vastaavan ammatillisen koulutuksen joutumista uudelleen arvioinnin kohteeksi.

Mutta eikö tällainen kehitys ole perimmältään myönteinen, etenkin kun työelämän kääntöpuolella näkyy monipuolisempaa ja korkeatasoisempaa taitoa, kykyä ja koulutusta edellyttävien ammattien selvä lisääntyminen? Toimihenkilöammatit lisääntyvät ja noin neljä palkansaajaa kymmenestä tekee jo jonkinlaista tietotyötä eli tuottaa, käsittelee tai jakaa tietoa.

Mikroelektroniikkaa hyödyntävä tietotekniikka vaikuttaa jo kaikkialla työelämään ja ammattitaitovaatimuksiin, vaikka työn laadut ja sisällöt kehittyvät eri työelämän aloilla eritahtisesti. On selvää, että vielä pitkään on suuri määrä työtehtäviä, joihin tarvitaan vain melko vähän koulutusta. Aivan ilmeisesti automaation vaikutuksesta eräät ammatit jopa köyhtyvät sisällöllisesti. 


\section{Koulutusmallin takinkääntö}

Mutta tulevaisuuden työ, siinä määrin kuin sitä löytyy, edellyttää kuitenkin entistä useammalta yhä korkeampaa ammattitaitoa ja samalla yhä korkeatasoisempaa koulutusta. Työ pitää hallita abstraktilla, käsitteellisellä otteella. Se edellyttää kykyä käsitellä tietokokonaisuuksia, vaatii taitoa sopeutua nopeasti uusiin tilanteisiin, soveltamistaitoa, sosiaalista joustavuutta ja mikä vähintään yhtä tärkeää - kykyä irtaantua entisistä, vanhentuneista toimintamalleista ja ajattelutavoista. Nuo kyvyt tulevat yksittäisissä työsuorituksissa saavutettua varmuutta ja rutiinimaista ammattitaitoa tärkeämmiksi. Työ vaatıl entistä niukemmin ennalta määriteltyjä, tiukasti rajattuja taitoja ja kapeita lopullisia käyttäytymismalleja, mutta kylläkin yhä enemmän tiedollista ja taidollista joustavuutta, luovaa ja ennakoivaa oppimista, sekä laaja-alaisia ja monikäyttöisiä perustietoja ja -taitoja. Työelämän peruskvalifikaatiotkin ovat asteittain muuttumassa. Samalla aikuiskoulutustarpeet tulevat yhä monipuolisemmiksi ja yksilöllisemmiksi.

Koulutuksen päämäärien kannalta erittäin mielenkiintoiselta vaikuttaa, että itse asiassa koko elämä yhteiskunnassa tulee parhaimmillaan edellyttämään samantapaisia taitoja kuin moderni työelämä. Pääodotukset tulevaisuuden ihmiselle, kansalaiselle, vapaa-aikana ja työelämässä toimivalle ovat hämmästyttävästi samansuuntaistumassa. Työelämän taitotietovaatimukset lähenevät koulutuksen itsearvoa korostavia sivistyksellisiä ja kasvatuksellisia näkökulmia.

Pohjïmmiltaan edellinen sisältää laajemminkin perinteisen koulutusmallin takinkäännön: taitoa luopua aikaisemmista henkisistä ja toiminnallisista käyttäytymismalleista uusien ja tarkoituksenmukaisempien hyväksi. Ei ainoastaan aikuiskoulutuksessa, vaan kaikenikäisten koulutuksessa olisi rohjettava siirtyä uusintavan, luovan ja ennakoivan oppimisen korostamiseen. Koulutuksen laadullisen kehittämisvaatimuksen taustalla korostuu laaja-alaisten ja monikäyttöisten perustietojen ja -taitojen, sekä yleissivistyksen että ammattisivistyksen merkityksen lisääntyminen. Tarvitaan perinteisen yleissivistyksen ja ammattisivistyksen rohkeata ja perinpohjaista uudelleen arviointia sekä ennen kaikkea niiden uutta synteesiä.

\section{Väestön ikärakenteen vaikutuksia aikuiskoulutukseen}

Aikuiskoulutusnäkymiin vaikuttaa ratkaisevasti väestön ikärakenteen kehitys. Vielä tällä hetkellä työikäisen väestömme osuus koko väestöstä on teollisuusmaiden korkeimpia ja työ- voiman ikärakenne on edullinerl.

Väestön ikärakenne on kuitenkin suhteellisen vauhdikkaasti muuttumassa. Sillä on kauaskantoisia vaikutuksia kaikille yhteiskuntapolitiikan alueille eikä vähiten koulutuspolitiikkaan.

Taulukko: Väestömuutokset Suomessa vuosina 1970-2030, 1000 henkeä

\begin{tabular}{lcccc}
\hline Ikä & $1970-$ & $1985-$ & $2000-$ & $2015-$ \\
& 1985 & 2000 & 2015 & 2030 \\
\hline $0-14$ & -168 & -103 & -99 & -92 \\
$15-40$ & +196 & -294 & -179 & -198 \\
$41-64$ & +94 & +378 & -58 & -206 \\
$65-$ & +195 & +155 & +227 & +133 \\
\hline Yhteensä & +318 & +136 & -108 & -363
\end{tabular}

Väestö

jakson

alussa $\quad 4600 \quad 4900 \quad 5100 \quad 4900$

Lähde: KELA Julkaisuja T9:27.

Alle 15-vuotiaiden määrä vähenee edelleen. 15-40-vuotiaiden joukko pienenee vuoteen 2000 mennessä nykyiseen verrattuna erittäin merkittävästi, lähes 300 000:Ila. Samaan aikaan yli 40-vuotiaiden työikäisten määrä lisääntyy lähes 400 000:Ila. Ja muutenkin Suomi on selvästi harmaantumassa.

Keskimääräistä vähemmän koulutusta saaneen vanhemman työvoiman lisääntyminen ja samaan aikaan vähän koulutusta vaativien ammattien ja työtehtävien määrän väheneminen luovat työpoliittisen aikapommin. Se saattaa hoitamattomana räjähtää ennen kuin yleisesti tunnettu vanhusten määrän kasvusta johtuva aikapommi ehtii edes kunnolla syntyä.

Peiliin tänään katsoessaan suuret ikäluokat, nelikymppiset ja hieman nuoremmat toteavat yltäneensä vakaaseen keski-ikään. Maamme työvoima on keski-ikäistymässä heidän mukanaan. Heillä pitäisi olla vielä pari-, kolmekymmentä vuotta eläkeikään. Näiden ikäluokkien uusiutumisesta ja uusiutumiskyvystä on ryhdyttävä pitämään hyvää huolta. Tämä on kansantaloutemme ja kansainvälisen kilpailukykymme sekä myös kulttuurimme kehittymisen kannalta aivan keskeistä.

Kannattaa muistaa, että suurista ikäluokista vain vajaalla 60 prosentilla on oppivelvollisuuskoulun jälkeinen tutkinto. Näistäkin osalla on ainoastaan ylioppilastutkinto, joten ammatillisesti suuntautunut perustutkintokin puuttuu noin puolelta suuriin ikäluokkiin kuuluvilta. Jo 50-luvun alkupuoliskolla syntyneillä ikäluokilla koulutustaso on selvästi korkeampi: $70 \%$ :lla 
heistä on perusasteen jälkeinen tutkinto. Nuorimmissa työmarkkinoille siirtyneissä ikäluokissa tuo osuus on jo 80 \%. Näyttää siltä, että myös aikuiskoulutusmahdollisuuksien paraneminen tapahtuu suurten ikäluokkien kannalta osin liian myöhään.

Vanhemmille ikäluokille, joilla ammatillisessa peruskoulutuksessakin on vielä vakavampia aukkoja, uusiutumisen ja kehittymisen mahdollisuus on luonnollisesti vähintään yhtä tärkeää kuin nuoremmille. Pienellä maalla ei ole inhimillisesti, kansantaloudellisesti eikä kulttuurisesti varaa yhteenkään menetettyyn sukupolveen eikä edes sen osaan. Varhaiseläkejärjestelmä ei voi olla suositeltavin ratkaisu yhteiskunnan sen paremmin kuin ikääntyvän työntekijän itsensäkään kannalta.

Suomessa tarvitaan ainutlaatuisen poikkeuksellinen ja mittava uudentyyppinen, painokkaasti ammatissa toimivaan aikuisväestöön kohdistuva koulutusponnistus.

\section{Aikuiskoulutettavuuden rajat ja niiden avartuminen}

Vaikeimmin ylitettäväksi ongelmaksi koulutuksessa saattavat muodostua aikuisen ihmisen koulutettavuuden rajat ja reunaehdot, ennen kaikkea ne luulotellut ja kuvitellut. On totta, että pellolta oli aikanaan helpompi siirtyä tehtaaseen kuin nyt kaatuvasta tehtaasta erikoiskoulutusta edellyttäviin toimihenkilö- tai ihmissuhdeammatteihin. Jämerän metallimiehen pukeminen esimerkiksi sosiaalityöntekijän kaapuun ei taida helposti onnistua, ei ainakaan millään lyhyellä kurssituksella. Jos vielä koulutus olisi jossain määrin mahdollista, asenteet eivät anna riittävästi periksi muuttua. Onneksi monet eivät joudu näin radikaalin ammatinvaihdon kohteeksi.

Mutta tulevaisuudessa kenen tahansa aikuisen kouluttautumisen on oltava mahdollista. Tilanne edellyttää uutta asennoitumista aikuisen kykyyn oppia uutta ja uudistua.

Monella aikuisella näyttää olevan pyrkimystä aliarvoida kykyjään oppia uutta. He antavat liian suuren painon aikaisemmille koulukokemuksilleen ja samalla aliarvostavat myöhemmin hankkimiensa laajojen informaalisten oppimiskokemusten merkitystä. Aikuisopiskelijoiden keskuudessa on vielä hämmästyttävän yleisenä luulo oppimiskyvyn nopeasta heikkenemisestä varhaisaikuisuuden jälkeen.

Motivoituminen opiskeluun ja muuhun osallistumiseen riippuu aikuisuuden olemukseen ja elämäntilanteisiin liittyvistä asioista. Koulutusoptimismi on kuitenkin aina paikallaan, ja se on useimmiten myös perusteltua aikuisopiskelijan kohdalla.
Kannattaa muistaa, että ihmisen koulutettavuuden rajat on aina historian aikana pystytty ylittämään. Joka tapauksessa tulevaisuudessa alati muuttuvassa työelämässä tarvitaan jatkuvaa ammattitaidon kohentamista, toistuvaa lisä- ja täydennyskoulutusta. Kerran saatu laadukkainkaan, perinpohjaisinkaan peruskoulutus ja ammattitaito eivät enää riitä koko elämän eväiksi. Jokainen joutuu kohtaamaan "henkilökohtaisen rakennemuutoksensa" ehkä useankin kerran elämänsä aikana.

Työ ja koulutus vuorottelevat ja limittyvät yksilön koko työuran ajan. Moderni ammatillinen koulutus voi olla vain jatkuvaa koulutusta; ammattiin ei olla koskaan lopullisesti valmiita

\section{Ammatillisen aikuiskoulutuksen käytännön järjestäminen ja rahoitus}

Aikuiskoulutuksen käytännön järjestelyjen kannalta hyvin merkittäväksi jo lyhyellä aikavälillä tulee osoittautumaan päätös, jonka valtioneuvosto on tehnyt ammatillisen aikuiskoulutuksen rahoitusjärjestelyistä.

Päätöksessä ammatillinen aikuiskoulutus jaetaan omaehtoiseen koulutukseen, henkilöstökoulutukseen ja työllisyyskoulutukseen.

Omaehtoiseen ammatilliseen aikuiskoulutukseen opiskelija hakeutuu omatoimisesti. Omaehtoisen, pitkäkestoisen koulutuksen tarjonnan rahoittamiseen osallistuvat valtio, opiskelijan kotikunta ja kohtuulliseksi katsottavalla osuudella opiskelija itse. Lyhytkestoisen omaehtoisen koulutuksen, jota järjestetään pääasiassa ammatillisten oppilaitosten kurssitoimintana, rahoittavat valtio ja opiskelija itse.

Henkilöstökoulutuksen rahoitusvastuu jää pääsääntöisesti työnantajalle. Julkisen hallinnon ja yksityisen sektorin henkilöstökoulutuksesta vastaa työnantaja joko järjestämällä itse tämän koulutuksen tai ostamalla sen muilta koulutuksen järjestäjiltä. Tällä hetkellä yritysten arvioidaan käyttävän työntekijöidensä koulutukseen 2-3 miljardia markkaa vuodessa.

Työllisyyskoulutuksen rahoituksesta vastaa valtio. Tavoitteena on kehittää työllisyyskoulutuksen hallintoa siten, että työvoimahallinto ostaa työllisyyskoulutuksena järjestettävän ammatillisen perus- ja jatkokoulutuksen ammatillisilta kurssikeskuksilta, oppilaitoksilta ja korkeakouluilta sekä muun koulutuksen edellä mainituilta tai muilta koulutuksen järjestäjiltä valtion tulo- ja menoarviossa työvoimaministeriön pääluokkaan osoitettavalla määrärahalla.

Rakennemuutoksen hallinta koulutuksen avulla edellyttää, että koulutusta voidaan käyttää ensisijaisesti ennaltaehkäisevänä keinona. Tästä syystä pitäisi erityisesti edistää omaeh- 
toiseen ammatilliseen koulutukseen osallistumista sekä henkilöstökoulutusta. Työllisyyskoulutukseen tulisi turvautua yleensä vasta sen jälkeen kun omaehtoisen ja henkilöstökoulutuksen mahdollisuudet on käytetty.

Oikeastaan työllisyyskoulutustermi olisi syytä korvata nykyaikaisemmalla nimellä. Joka tapauksessa työllisyyskoulutuksen tavoitteita ja opetussuunnitelmia pitäisi lähentää vastaavan omaehtoisen aikuiskoulutuksen kanssa ja samalla tehdä ammatillisista kurssikeskuksista aikuiskoulutuskeskuksia.

Ammatillisen aikuiskoulutuksen käytännön järjestelyissä, jotka vaikuttavat kaikessa aikuisväestön koulutuksessa, olisi otettava huomioon seuraavat kehitysnäkymät:

- koulutustarpeiden tyydyttämisen yksilöllistyminen ja erikoistuminen,

- koulutuksen joustavuusvaatimusten lisääntyminen,

- koulutuksen itseohjautuvan säätelyn kasvaminen sekä

- koulutuksen rahoituksen ohjautuminen pääasiassa koulutuksen kysynnän kautta.

Koulutustoiminnan ohjautuminen kysynnän ja tarjonnan välisillä markkinamekanismeilla ei luonnollisestikaan ole riskitöntä. Tähän asti on henkilöstökoulutuksen sisällä ollut nähtävissä vaikeita tasa-arvovinoumia koulutuksen jakautumisessa eri työntekijäryhmien ja elinkeinoalojen välillä. Ammatillisen aikuiskoulutuksen polarisoitumista on kyettävä vähentämään ja ehkäisemään myös yhteiskunnan rahoitus- ja muin keinoin.

Ammatillisen aikuiskoulutuksen järjestämisen avainkysymyksessä, rahoitusjärjestelyissä, pitäisi päästä nopeasti etenemään. Lopullinen kädenvääntö koulutuskustannusten jakautumisessa työnantajien, työntekijöiden ja muun yhteiskunnan kesken on vielä edessä.

Aikuisopiskelijan halukkuus osallistua ammatilliseen koulutukseen riippuu useimmiten hänen koulutusvapaansa aikaisesta toimeentuloturvasta. Tarkoituksena on, että omaehtoisesti osallistuvien opintotukijärjestelmää kehitetään siten, että 30 vuotta täyttäneille päätoimisesti koulutukseen osallistuville taataan toimeentuloturva, joka on mitoitettu vähintään työttömyyden perusteella maksettavan perusturvan mukaisesti. Henkilöstökoulutukseen työntekijä osallistuu työnantajan määräämänä työ-, virka- tai toimiehtosopimuksen mukaisin eduin. Työllisyyskoulutuksen osallistuva henkilö saa tähän koulutukseen jo nykyisin kuuluvan toimeentuloturvan.

Omaehtoisesti koulutukseen osallistuvan aikuisopiskelijan toimeentuloturvan kehittämiseksi on 1.7.1987 aloitettu kolme vuotta kestävä aikuisopintorahakokeilu. Aikuisopintorahaa voidaan maksaa työelämässä viisi vuotta toi- mineelle 30 vuotta täyttäneelle henkilölle, joka aloittaa vähintään kahdeksan viikkoa kestävät täysipäiväiset opinnot. Aikuisopintorahaa voi saada $20 \%$ vakiintuneesta tulotasosta, kuitenkin vähintään 700 markkaa ja enintään 2000 markkaa. Tuen lisäksi saajalla on mahdollisuus normaaliin opintotukeen.

Omaehtoisesti aikuisopiskeluun osallistuvan toimeentuloturvan kehittämisessä tarvitaan vielä huomattavia yhteiskunnan jatkotoimenpiteitä pidettäessä päämääränä sellaista aikuiskoulutusjärjestelmää, joka takaa koko aikuisväestölle jatkuvan koulutuksen periaatteen edellyttämän monimuotoisen ja joustavan todellisen koulutusoikeuden kaikissa yksilön elämänvaiheissa.

\section{Kulttuurin rakennemuutos ja aikuiskoulutus}

Koulutus tuottaa huonoimmillaankin ja teknisimmilläänkin nimenomaan kulttuuria. Kasvatus on aina kulttuurisidonnaista ja oppilaitos on yhteiskunnan merkittävin kulttuuri-instituutio.

Kautta aikojen on käynyt niin, että kun ihmisen käyttämä tekniikka muuttuu, myös kulttuurijärjestelmä on ruvennut uusimaan rakenteitaan.

Suomi ei tänään ole ainoastaan talouden ja työelämän rakennemuutoksen keskellä. Näköpiirissä siintää myös henkisen kulttuurin murros, mikä kantaa sisällään asteittaisen siirtymisen uudentyyppiseen kulttuurikauteen. Tälle kulttuurikaudelle leimallista on kulttuurien yhdentyminen, yhteisten piirteiden voimistuminen, minkä uusi tietotekniikka tietokoneineen, satelliitteineen ja taivaskanavineen mahdollistaa sekä toisaalta paikallisten ja kansallisten kulttuurien erityispiirteiden ja omaleimaisuuden niukentuminen. Uuden kulttuurivaiheen keskeisin tekijä on viestintäympäristössä tapahtuva muutos.

Sähköisten viestimien ja muun uuden teknologian vaikutus kulttuurimurroksessa tarjoaa ristiriitaisia näköaloja. Pienten kansallisvaltioiden omasta tahdonmuodostuksesta ja valittavista toimenpiteistä pitäisi riippua paljolti se, käytetäänkö uuden teknologian ja viestinnän mahdollisuuksia kansallisen kulttuurin voimistamiseen. Toinen mahdollisuus on ajautua kulttuurisen muutoksen virrassa ilman omatahtoista kehittämistoimintaa. Maailmanlaajuiset tiedonsiirtoverkostot eivät meitä missään tapauksessa sivuuta, eikä yhä vinhemmin leviävä globaali massakulttuuri koskaan tule toimimaan meidän ehdoillamme eikä suomen kielellä. Teknosysteemi ravistelee jo ankarasti kansallisvaltiota.

1990-luvulle tultaessa on Suomessa välttämätöntä keskittyä kansallisen kulttuurin voi- 
mistamiseen ja sen ehtona olevan kansalaisten omatoimisen aktiivisuuden ja luovuuden kehittämiseen. Pienen kansallisen kulttuurin olemassaolon edellytys ja sen piirissä elävien ihmisten hyvinvoinnin edellytys on, että kulttuurisia erityispiirteitä ei sysätä syrjään, vaan terveen itsetuntoista kansallista omaleimaisuutta vahvistetaan. Tämä tapahtuu painotetusti koulutus- ja kasvatustoiminnan avulla.

Suuri yhteiskunnallinen ja samalla keskeinen aikuiskoulutuspoliittinen kysymys on suomalaisen kulttuurin toimintastrategian löytäminen. Siinä on olennaista omaleimaisen kansallisen kulttuurin ja myönteisten kansainvälisten kulttuurivaikutteiden tarkoituksenmukainen yhdistely. Kulttuurin kehittäminen on otettava koko yhteiskuntapolitiikkamme päämääräksi. Yhteiskuntamme kaikkien lohkojen kehittämisen tavoitteena tulisi olla suomalaisen kulttuurivaltion henkisen ja aineellisen itsenäisyyden ja omavaraisuuden turvaaminen.

Tästä tuoreesta näkökulmasta tarkasteltuna kansansivistysajattelu saattaa olla kokemassa aivan ennen aavistamatonta renesanssia, ei toki vanhakantaisen haaveilevana taaksepäin tuijottamisena, vaan uudentyyppisenä kehittämis- ja kasvuajatteluna sekä suhtautumistapana ihmiseen, yhteiskuntaan, kulttuuriin ja kansainvälisyyteen.

Yhdeksättätoista vuosisataa on joskus pidetty kansansivistyksen vuosisatana. Voitaisiinko ennakoida, että kahdeskymmenesensimmäinen vuosisata olisi sivistyksen vuosisata?

Tässä maisemassa ja visiossa aikuiskoulutuksella ja sen uudistajilla on tavattoman paljon miettimisen arvoista.

\section{Teollisuusyhteiskunnan koulupolitiikasta jälkiteollisen tietoyhteiskunnan koulutuspolitiikkaan}

Jos meneillään olevaa syvälle ulottuvaa rakennemuutosta aiotaan pystyä hallitsemaan koulutuksella, tarvitaan uutta koko väestön koulu- tusstrategiaa. On koittanut aika siirtyä teollisuusyhteiskunnan koulupolitiikasta jälkiteollisen tietoyhteiskunnan koulutuspolitiikkaan. Uudella koulutus- ja kulttuuripolitiikalla on koko väestölle mahdollistettava riittävä tieto-, taito- ja luovuusvaranto, jotta elämisen laatu ja täysipainoinen osallistuminen rakennemuutoksen hallintaan ja yleensä yhteiskunnan kehittämiseen turvattaisiin jokaiselle.

\section{Lähteet}

Aikuiskoulutuksen kehittäminen 1988-1990. 1987. Opetusministeriö. Aikuiskoulutusneuvoston julkaisuja 2.

Jatkuvan koulutuksen projektiryhmän muistio. 1986. Opetusministeriön työryhmien muistioita 1986:1. Helsinki: Valtion painatuskeskus.

Kortteinen, M. 1987. Hallittu rakennemuutos. Helsinki: Hanki ja jää.

Lehtisalo, L. \& Raivola, R. 1986. Koulutuspolitiikka ja koulutussuunnittelu. Porvoo-Helsinki-Juva: WSOY.

Livslang laering. Norges offentlige utredningar 1986:23. Oslo-Bergen-Stavanger-Tromsø: Universitetsforlaget.

Pääministeri Harri Holkerin hallituksen ohjelma. 1987. Helsinki: Valtion painatuskeskus.

Taloudellinen suunnittelukeskus. 1986. Harmaantuva Suomi 2030? Helsinki: Valtion painatuskeskus.

Unescon 4. aikuiskasvatuskonferenssi 19851987. Suomen Unescotoimikunnan julkaisuja No 38. Helsinki: Yliopistopaino.

Valtioneuvoston periaatepäätös ammatillisen aikuiskoulutuksen rahoittamisen suunnitteluperiaatteista. Valtioneuvoston yleinen istunto 5.3.1987.

von Wright, G. H. 1987. Tiede ja ihmisjärki. Helsinki: Otava. 


\section{AIKUISKASVATUS \\ The Finnish Journal of Adult Education \\ Vol. 8,1/88 \\ ISSN 0358-6197 \\ Summary}

Lehtisalo, Liekki. 1988. Structural Change and Education of the Adult Population.

The article looks into the possibilities of adult education as a tool in the controlled structural change taking place in society, working life, and the cultural scene. The changes referred to presuppose entirely new type of total population education strategy based on the principle of flexible continuing education. The structural change means discarding the education policy of an industrialized society and putting into practice that of a post-industrial society. The new education policy must be one that will ensure each member of society with the necessary knowledge, skill and creative capacities. 